\title{
Analysis Students Mistakes of Mathematics Major of IAIN Jember in Trigonometry Operations Precondition Calculus Courses
}

\author{
Nur Ega Septiandi*, Novita Nurul Aini, Happy Firda Nuril Umami \\ Program Studi Tadris Matematika Fakultas Tarbiyah dan Ilmu Keguruan Institut Agama Islam Negeri Jember \\ Email*: septiandinurega@gmail.com
}

\begin{abstract}
Not a few students mathematics education of IAIN Jember experience obstacles in studying Calculus courses. This can be seen from many students who say that calculus courses are difficult and the results of the student calculus pretest. The lack of mastery in trigonometric operations which is a prerequisite for calculus courses is one reason. Therefore, error analysis is needed to identify the types of errors and the tendency of errors experienced by students in working on trigonometric problems which are the prerequisite material for calculus courses. Data collection in this study was carried out by the method of tests and interviews, meanwhile the data analysis used descriptive analysis. Through data analysis, it can be concluded that the errors experienced by students in working on trigonometric operations as a prerequisite for calculus courses are errors of fact, concept errors, and skills errors. Of the three errors, what turns out to be a tendency to error is a fact error. In addition, the cause of the error was the very lack of understanding of the concepts that exist in the material trigonometric operations.
\end{abstract}

Keywords: Mistakes, Trigonometry operations, Calculus.

\section{INTRODUCTION}

Faculty of Education and Teacher Training IAIN Jember is one of the faculties which produce the personnel. The faculty has several programs of study, that is study program of Islamic Education, Arabic Education, Islamic Educational Management, Madrasah Ibtidaiyah Teacher Education, Early Childhood Education, Biology Education, Natural Science Education, Social Science Education, English Education, Mathematics Education. Study program of Mathematics Education already opened in the academic and year 2015/2016 and began to accept students of bachelor program education. The curriculum Faculty of Education and

Teacher Training, in particular study program of Mathematics Education, consist a group of General Subjects (MKU), Basic Skills Courses (MKDK), Skill Courses (MKK), and a group of elective courses.

Some of the courses in the course group skills is a course that must be followed by all student teachers of mathematics. Calculus I is one of the courses that must be followed by all students of study program Mathematics Education. This course involves the relationship of mathematical ideas, namely the ideas of Trigonometry, Algebra, and Geometry. Therefore, to study Calculus I needed other knowledge as a prerequisite.

There are a number of expert opinions with regard to the teaching of mathematics. In preparing a good curriculum, first required the analysis of concepts in one field of study, and then note the relationships between these concepts, so it can know which concepts be a prerequisite for another concept (goodlad, 1966 :12).
Mathematics is a subject of great precision in which concepts can be defined accurately to provide a solid foundation and structure of his theories are continuitas (Tall, 1981: 151). Based on these two opinions, it can be concluded that mathematics should be taught and learned gradually based on the hierarchy of mathematics.

This will certainly make it easy for students who want to learn. In other words that the understanding of a concept can be formed if the concept was connected with a concept that has been known previously. If a student not understand the concept or the previous subject it will be difficult for students to understand the subject further. So in learning mathematics, the experience of prior learning is very necessary as a basis to learn the subject advanced mathematics.

In particular, calculus courses requires a subject has a prerequisite. This refers to the opinion of Simmons, which stated that basic knowledge as a prerequisite calculus courses is Trigonometry, Algebra, and Geometry (Simmons, $1981: 1$ ). Nyaumwe also said that in studying calculus should have knowledge about the mathematical concepts of Trigonometry, Algebra and Geometry in High School (Nyaumwe, $2008: 190$ ).

Based on some opinions above, it can be concluded that to master calculus required math knowledge in High School such as Trigonometry, Algebra and Geometry. All three subjects are a prerequis ite for calculus courses. However, in this research, the author only limit on subject based on the trigonometric topics in the calculus courses.

Based on the experience of researcher in the parenting calculus courses found the presence of errors in the completion of the questions calculus courses in the 
form of errors concept and not a concept. It is based on some results of the study, among other things, Rahmawati which concluded that there are still many students of Mathematics Education Unipdu semester II of academic year 2016/2017 made a mistake and the mistake is not a concept in a course of calculus (Rahmawati, 2017: 90). This means the experience of learning mathematics in High School mainly matter of trigonometry related calculus greatly affect the procces of learning calculus in college.

From the description that has been described above, the author try to analyze and reveal these kind of errors, the tendency error, and the cause of error skills, error consepts, and error of principle committed by students of study program mathematics IAIN Jember with regard to the settlement of the questions of trigonometry in High School as a prerequisite for calculus.

\section{MATERIALS AND METHODS}

This research is a mixed method. The mixed method is a combination quantitative and qualitative methods. Quantitative Data collection methods for numerical data that can be discussed. Qualitative methods are used for discuss and discuss successful empathy and process, procedural activities, assessing, and evaluating (Mukhlis, 2018: 20). The subject of the research was college students of Mathematics Major of IAIN Jember, East Java, Indonesia amounted 30 college students while the location of research also in IAIN Jember. Data collection was conducted by using test and interview. Test was conducted to acquire data about the errors made by college students based on the stages of Newman analysis. In this research test was arranged from UN test and SBMPTN test about five items and selected according the condition of this location. While the interview was conducted to acquire data in the form of words, which were spoken expressions about the errors made by college students in solving mathematics test. Interview conducted in this research was a semistructured interview according five stages of Newman's Error Analysis. There were three college students used as subjects of interview, each of them was taken from the group of students who had high, medium, and low abilities. College students were categorized in lowability group if the score was less than the lower quartile, if score was more than or equal to the lower quartile and less than the upper quartile were categorized into medium-ability group, while if score was more than or equal to the upper quartile were categorized into highability group. Data analysis used in this research referred to the guidance of Newman's Error Analysis that included five stages: reading, comprehension, transformation, process skills, and encoding (White dalam Farihah, 2014: 450).

\section{RESULTS AND DISCUSSION}

\section{Results}

This research data obtained from the test results which were written answer sheets, interview with interview guidelines, and the instruments interview used to identify the students error. Interview Data is used to know the percentage of mastery students of the trigonometry subject based on the perception of 30 students, it can be seen at figure 1 .

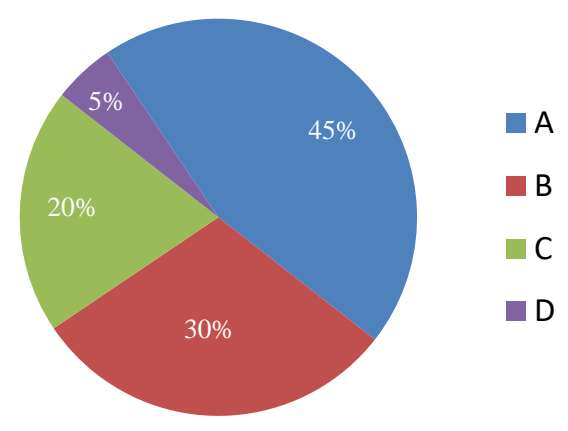

Figure 1. Percentage of Student Interview Results

In figure above, it can be seen that the sum of students who have a comprehension of the trigonometry subject which is denoted by $\mathrm{A}$ is $45 \%$. The sum of students who have a comprehension of the trigonometry subject but they cannot mention the ratio, identity and trigonometry formula which is denoted by B is $30 \%$. The sum of students who have a comprehension of the trigonometry subject, they can mention the ratio, identity, and trigonomtery formula but cannot apply the ratio, identity, and trigonometry formula to solve the problem which is denoted by $\mathrm{C}$ is $20 \%$. The sum of students who have a comprehension of the trigonometry subject, they can mention the ratio, identity, and trigonometry formulas and they can apply the ratio, identity and trigonometry formulas to solve the problem but they cannot determine the final answer which is denoted by $\mathrm{D}$ is $5 \%$.

Moreover, it is also used to analyze the students errors in solving trigonometry problems that can be seen in table 1 . 
Table 1. Types of Students Errors.

\begin{tabular}{|c|c|c|c|c|c|}
\hline \multirow{2}{*}{ Students' Number } & \multicolumn{5}{|c|}{ Types of Errors } \\
\hline & Question 1 & Question 2 & Question 3 & Question 4 & Question 5 \\
\hline 1. & $\mathrm{~N}$ & $\mathrm{~N}$ & $\mathrm{~N}$ & $\mathrm{C}, \mathrm{T}, \mathrm{P}, \mathrm{E}$ & $\mathrm{N}$ \\
\hline 2. & $\mathrm{C}, \mathrm{T}, \mathrm{P}, \mathrm{E}$ & $\mathrm{C}, \mathrm{T}, \mathrm{P}, \mathrm{E}$ & $\mathrm{C}, \mathrm{T}, \mathrm{P}, \mathrm{E}$ & $\mathrm{C}, \mathrm{T}, \mathrm{P}, \mathrm{E}$ & $\mathrm{N}$ \\
\hline 3. & $\mathrm{C}, \mathrm{T}, \mathrm{P}, \mathrm{E}$ & $\mathrm{C}, \mathrm{T}, \mathrm{P}, \mathrm{E}$ & $\mathrm{C}, \mathrm{T}, \mathrm{P}, \mathrm{E}$ & $\mathrm{N}$ & $\mathrm{N}$ \\
\hline 4. & $\mathrm{~T}, \mathrm{P}, \mathrm{E}$ & $\mathrm{N}$ & $\mathrm{N}$ & $\mathrm{T}, \mathrm{P}, \mathrm{E}$ & $\mathrm{N}$ \\
\hline 5. & M & $\mathrm{N}$ & $\mathrm{N}$ & $\mathrm{N}$ & $\mathrm{N}$ \\
\hline 6. & M & $\mathrm{C}, \mathrm{T}, \mathrm{P}, \mathrm{E}$ & $\mathrm{N}$ & $\mathrm{N}$ & $\mathrm{N}$ \\
\hline 7. & M & $\mathrm{C}, \mathrm{T}, \mathrm{P}, \mathrm{E}$ & $\mathrm{C}, \mathrm{T}, \mathrm{P}, \mathrm{E}$ & $\mathrm{C}, \mathrm{T}, \mathrm{P}, \mathrm{E}$ & $\mathrm{N}$ \\
\hline 8. & $\mathrm{~T}, \mathrm{P}$ & $\mathrm{C}, \mathrm{T}, \mathrm{P}, \mathrm{E}$ & $\mathrm{C}, \mathrm{T}, \mathrm{P}, \mathrm{E}$ & $\mathrm{C}, \mathrm{T}, \mathrm{P}, \mathrm{E}$ & $\mathrm{N}$ \\
\hline 9. & $\mathrm{~T}, \mathrm{P}$ & $\mathrm{P}, \mathrm{E}$ & $\mathrm{C}, \mathrm{T}, \mathrm{P}, \mathrm{E}$ & $\mathrm{T}, \mathrm{P}, \mathrm{E}$ & $\mathrm{C}, \mathrm{T}, \mathrm{P}, \mathrm{E}$ \\
\hline 10. & M & $\mathrm{P}, \mathrm{E}$ & $\mathrm{P}, \mathrm{E}$ & $\mathrm{N}$ & $\mathrm{N}$ \\
\hline 11. & M & $\mathrm{T}, \mathrm{P}, \mathrm{E}$ & $\mathrm{C}, \mathrm{T}, \mathrm{P}, \mathrm{E}$ & $\mathrm{C}, \mathrm{T}, \mathrm{P}, \mathrm{E}$ & $\mathrm{C}, \mathrm{T}, \mathrm{P}, \mathrm{E}$ \\
\hline 12. & M & $\mathrm{N}$ & M & $\mathrm{N}$ & $\mathrm{N}$ \\
\hline 13. & $\mathrm{P}$ & $\mathrm{N}$ & $\mathrm{N}$ & $\mathrm{N}$ & $\mathrm{N}$ \\
\hline 14. & $\mathrm{P}$ & $\mathrm{N}$ & $\mathrm{C}, \mathrm{T}, \mathrm{P}, \mathrm{E}$ & $\mathrm{C}, \mathrm{T}, \mathrm{P}, \mathrm{E}$ & $\mathrm{C}, \mathrm{T}, \mathrm{P}, \mathrm{E}$ \\
\hline 15. & $\mathrm{P}$ & $\mathrm{N}$ & $\mathrm{C}, \mathrm{T}, \mathrm{P}, \mathrm{E}$ & $\mathrm{T}, \mathrm{P}, \mathrm{E}$ & $\mathrm{T}, \mathrm{P}, \mathrm{E}$ \\
\hline 16. & $\mathrm{P}, \mathrm{E}$ & $\mathrm{N}$ & $\mathrm{N}$ & $\mathrm{N}$ & $\mathrm{N}$ \\
\hline 17. & $\mathrm{P}, \mathrm{E}$ & $\mathrm{P}, \mathrm{E}$ & $\mathrm{N}$ & $\mathrm{N}$ & $\mathrm{N}$ \\
\hline 18. & $\mathrm{P}, \mathrm{E}$ & $\mathrm{N}$ & $\mathrm{N}$ & $\mathrm{P}, \mathrm{E}$ & $\mathrm{N}$ \\
\hline 19. & $\mathrm{P}, \mathrm{E}$ & $\mathrm{N}$ & $\mathrm{N}$ & $\mathrm{C}, \mathrm{P}, \mathrm{E}$ & $\mathrm{N}$ \\
\hline 20. & $\mathrm{P}, \mathrm{E}$ & $\mathrm{N}$ & $\mathrm{C}, \mathrm{T}, \mathrm{P}, \mathrm{E}$ & $\mathrm{P}, \mathrm{E}$ & $\mathrm{P}, \mathrm{E}$ \\
\hline 21. & $\mathrm{P}, \mathrm{E}$ & $\mathrm{P}, \mathrm{E}$ & $\mathrm{P}, \mathrm{E}$ & $\mathrm{P}, \mathrm{E}$ & $\mathrm{P}, \mathrm{E}$ \\
\hline 22. & $\mathrm{P}, \mathrm{E}$ & $\mathrm{P}, \mathrm{E}$ & $\mathrm{N}$ & $\mathrm{N}$ & $\mathrm{N}$ \\
\hline 23. & $\mathrm{P}, \mathrm{E}$ & $\mathrm{P}, \mathrm{E}$ & $\mathrm{C}, \mathrm{T}, \mathrm{P}, \mathrm{E}$ & $\mathrm{N}$ & $\mathrm{N}$ \\
\hline 24. & $\mathrm{C}, \mathrm{T}, \mathrm{P}, \mathrm{E}$ & $\mathrm{N}$ & $\mathrm{P}, \mathrm{E}$ & $\mathrm{P}, \mathrm{E}$ & $\mathrm{P}, \mathrm{E}$ \\
\hline 25. & $\mathrm{P}, \mathrm{E}$ & $\mathrm{P}, \mathrm{E}$ & C, T, P,E & C, T, P,E & $\mathrm{C}, \mathrm{T}, \mathrm{P}, \mathrm{E}$ \\
\hline 26. & M & $\mathrm{C}, \mathrm{T}, \mathrm{P}, \mathrm{E}$ & $\mathrm{N}$ & $\mathrm{C}, \mathrm{T}, \mathrm{P}, \mathrm{E}$ & $\mathrm{C}, \mathrm{T}, \mathrm{P}, \mathrm{E}$ \\
\hline 27. & $\mathrm{P}, \mathrm{E}$ & $\mathrm{P}, \mathrm{E}$ & $\mathrm{P}, \mathrm{E}$ & $\mathrm{P}, \mathrm{E}$ & $\mathrm{P}, \mathrm{E}$ \\
\hline 28. & $\mathrm{P}, \mathrm{E}$ & $\mathrm{P}, \mathrm{E}$ & $\mathrm{P}, \mathrm{E}$ & C, T, P,E & $\mathrm{P}, \mathrm{E}$ \\
\hline 29. & C, T, P,E & C, T, P,E & $\mathrm{N}$ & $\mathrm{N}$ & $\mathrm{N}$ \\
\hline 30. & M & $\mathrm{P}, \mathrm{E}$ & $\mathrm{C}, \mathrm{T}, \mathrm{P}, \mathrm{E}$ & $\mathrm{N}$ & $\mathrm{N}$ \\
\hline
\end{tabular}

Notes:

$\begin{array}{llll}\mathrm{R}=\text { Reading Error } & \mathrm{C}=\text { Comprehension Error } & \mathrm{T}=\text { Transformation Error } & \mathrm{P}=\text { Process skills Error } \\ \mathrm{E}=\text { Encoding Error } & \mathrm{N}=\text { Unanswered Questions } & \mathrm{M}=\text { Difficulties not found } & \end{array}$

Based on Table 1 above, it can be seen that none of the students who were able to answer the overall of five questions trigonometry correctly. Table 1 above shows that at the stage of reading which is denoted by $R$, of the five trigonometric problems that were given, none of the students made errors. At the stage of understanding is denoted by C, 4 students $(13.3 \%)$ cannot understand question number 1.7 students $(23.3 \%)$ cannot understand question number 3. 10 students (33.3\%) cannot understand question number 4. 5 students $(16,7 \%)$ cannot understand question number 5 . While on the stage of transformation is denoted by T, 7 students $(23,3 \%)$ made an error of transformation on question number 1 and question number 2. 11 students $(36,6 \%)$ made an error of transformation on question number 3 . 10 students $(33,3 \%)$ made an error of transformation on question number 4.5 students $(16,6 \%)$ made an error of transformation on question number 5. At this stage of transformation, the students made errors because not being able to mention and use a trigonometry identity in working on the problems or students use the identity but can not apply on the problem properly. On the stage of process skills is denoted by $\mathrm{P}, 21$ students $(70 \%)$ made an error in the process of working on question number 1. 18 students $(60 \%)$ made an error in the process of working on question number 2. 17 students $(56,6 \%)$ made an error in the process of working on question number 3. 18 students $(60 \%)$ made an error in the process of working on question number 4.11 students $(36,6 \%)$ made an error in the process of working on question number 5. It means that in this stage, students often made error in applying the formula written at transformation or students could not perform mathematical operations related with the trigonometry 
identity used. At the stage of determination answers is denoted by E. 16 students $(53,3 \%)$ made an error in determining the answers on question number 1.18 students $(60 \%)$ made an error in determining the answers on question number 2. 17 students $(56,6 \%)$ made an error in determining the answers on question number 3 . 18 students $(60 \%)$ made an error in determining the answers on question number 4. 11 students $(36,6 \%)$ made an error in determining the answers on question number 5. At the stage of determination answers, many errors made by students in determining and writing the final answer. The error of that stage, as a result of errors in the stage of process skills and transformation. but there are also a few students who are less conscientious in writing the final answer though they passed on the stage of process skills.

\section{Discussion}

In general, the recapitulation of students error percentage in working on trigonometry problems can be presented in figure 2 below.

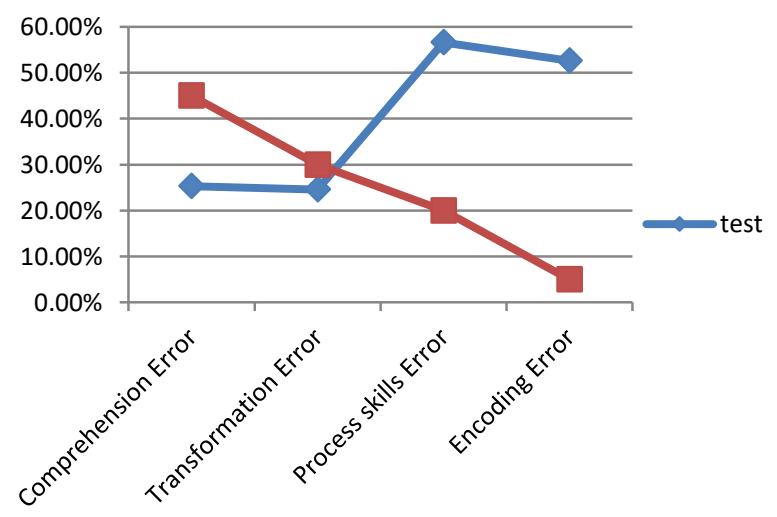

Figure 2. Recapitulation of Students Error Percentage.

In figure 2 , it can be seen that the largest proportion of errors made by students on the stage of process skills is $56,6 \%$ and encoding is $52.6 \%$. This occurs inasmuch as students do not understand the procedure needed to carry out operation trigonometric accurately although some of them were able to mention trigonometry identity but wrong in applying the identity so students cannot solve trigonometric problems perfectly, it also had a profound effect on deciding the final answer.

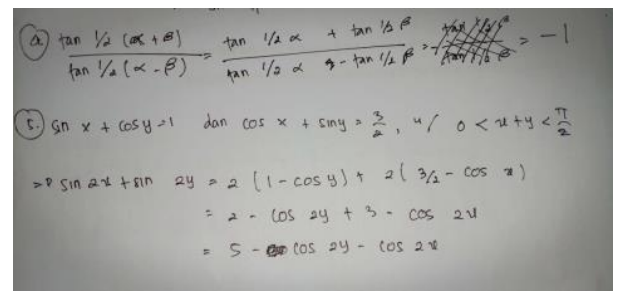

Figure 3. Student Mistakes on Numbers 4 and 5

These errors made by students, especially on questions number 4 and 5 . Next is the stage of transformation that is $24,6 \%$, then the stage of comprehension that is $25.3 \%$, and the last is the stage of reading, that is $0 \%$.

At the stage of reading none of the students who made errors in working out five trigonometric problems. This occurs inasmuch because the given problem not about story problem, but the five questions are about the base that only requires comprehension of concept and implementation of identity on the problems as well as the appropriate of process skills. With interviews, students suggested that to work on the problems trigonometric so rarely students made errors in reading .

The form error at the stage of comprehension is students are not able to understand the questions requested although they can read the questions well, because the question requires a high level of understanding. From the results of the test and interview, many students made comprehension errors on questions number $1,2,3,4$, and 5 .

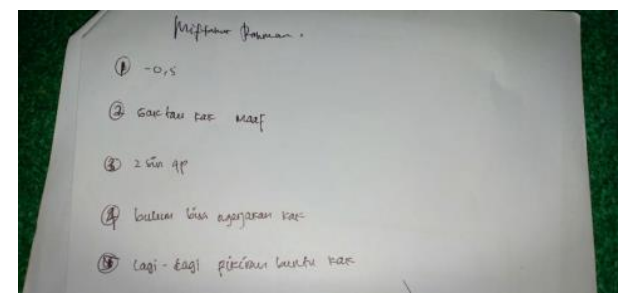

Figure 4. Student Mistakes at The Stage of Comprehension.

It is proved from comprehension error on question number 1, the students cannot understand the question "Value of $\cos 1200^{\circ}$. Q Question number 2 the students cannot understand the question $\frac{\tan ^{2} 30^{\circ} \sin ^{2} 60^{\circ}+\tan ^{2} 60^{\circ} \cos ^{2} 30^{\circ}}{\sin ^{2} 30^{\circ} \cos ^{2} 60^{\circ}}$. Question number 3 the students cannot understand the question " $\sin 3 p+$ $\sin p$ ". Question number 4 the students cannot understand the question "In a ABC triangle, if the angle $\alpha$ is dealing with the a side and angle $\beta$ is dealing with the $\mathrm{b}$ side. So $\frac{\tan \frac{1}{2}(\alpha+\beta)}{\tan \frac{1}{2}(\alpha-\beta)}$. Question number 5 the students cannot understand the question " If $\sin x+\cos y=1$ and $\cos x+\sin y=\frac{3}{2}$ so for $0<x+y<\frac{\pi}{2}$, define $\sin 2(x+y)$ "'.

The forms of student errors at the stage of transformation in this research that students cannot identity the appropriate trigonometry identity to solve and work on the problems given. At this stage, there are $24.6 \%$ of the students made errors on questions number $1,2,3,4$, and 5 . 


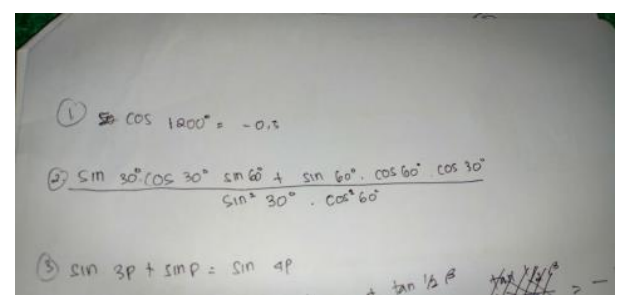

Figure 5. Student Mistakes at The Stage of Transformation.

The errors often made by students at this stage are students cannot write the ratio and identity, which they used to solve the question as an example question number 1 , students cannot write the trigonometric ratio used to answer the question "Value of $\cos 1200^{\circ}$. Question number 2 students cannot write the trigonometric ratio used to answer the question $\frac{\tan ^{2} 30^{\circ} \sin ^{2} 60^{\circ}+\tan ^{2} 60^{\circ} \cos ^{2} 30^{\circ}}{\sin ^{2} 30^{\circ} \cos ^{2} 60^{\circ}}$. Question number 3 students cannot write the formula of trigonometry double angles used to answer the question " $\sin 3 p+\sin p$ ". Question number 4 students cannot write trigonometry formulas used to answer the question "In a ABC triangle, if the angle $\alpha$ is dealing with the a side and angle $\beta$ is dealing with the $\mathrm{b}$ side. So $\frac{\tan \frac{1}{2}(\alpha+\beta)}{\tan \frac{1}{2}(\alpha-\beta)}$. Question number 5 students cannot write trigonometry formulas used to answer the question "If $\sin x+\cos y=1$ and $\cos x+$ $\sin y=\frac{3}{2}$ so for $0<x+y<\frac{\pi}{2}$, define $\sin 2(x+y)$ ".

The stage of process skills is a process in which students have skills to solve trigonometry problems accurately. Error made by students based on this research is students cannot write the steps in solving problems. This error may occur since the stage of comprehension and transformation so that they affect directly to the stage of process skills.

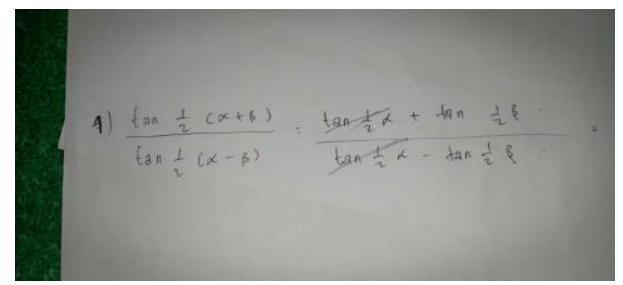

Figure 6. Student Mistakes at The Stage of Process Skills.

For example, on question number 4 of trigonometry problem only one student who can working the problem with steps accurately without facing difficulties. Question number 4, the error of student started from writing wrong formula so the skill in the process of solving also facing error. Meanwhile, question number 5 most students can understand the question and are able to write a formula accurately, buy they cannot calculate the appropriate procedure so that the determination of final result also facing error.
At the stage of encoding, students error occurred in writing the final answer. This stage is the last stage which students made errors at this stage is $52,6 \%$.

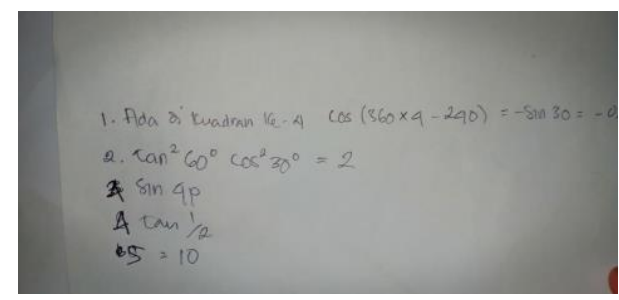

Figure 7. Student Mistakes At The Stage Of Encoding.

Errors in the writing and determining of final answer is closely related to the stage of comprehension and the stage of process skills. If the student made an error on the second stage, then most likely at the stage of encoding, they will also made errors.

The causative factors from all errors made by students in working trigonometry problems that students cannot understand the question requested, students cannot catch trigonometry concepts, students cannot determine the identity should be used to solve trigonometry problems accurately, students less practice to solve variations about trigonometry, students are less rigorous in determining and writing the final answer. Overall, the results of this research shows that the largest proportion of students error is at the stage of process skills and encoding as well as comprehension.

\section{CONCLUSION}

Based on the results of the test and interview with students, the researchers concluded that the forms of students errors viewed from the stage of Newman's Error Analysis (NEA) is as follows:

1. Reading Stage

Students can read the question fluently. The given question is trigonometry problems presented in Indonesian and do not use difficult terms.

2. Comprehension Stage

Students errors made at this stage are less catch trigonometry concepts. So students cannot understand the question requested.

3. Transformation Stage

At this stage, students often make errors because they cannot catch the ratio, identity and trigonometry formulas. So students cannot determine the ratio, identity and trigonometry formulas used to solve problem accurately. Consequently, students misdetermine the method of solving trigonometry problems.

4. Process Skills Stage

At this stage, students make a lot of error because they made errors at the previous stage, that is the stage of comprehension and transformation. So 
students cannot to carry out the problem with the process and procedure perfectly.

5. Encoding Stage

This stage depends on the stages 2, 3, and 4. If students made errors at that stage, then the most likely at the stage of encoding students also make errors.

\section{ACKNOWLEDGEMENTS}

With full respect, researchers say many thanks to :

1. Parents researchers who always giving spirit through their prayers.

2. Prof. Dr. H. Babun Suharto, S.E., M.M. as the Rector of State Islamic Institute of Jember.

3. Dr. Hj. Mukni'ah, M. Pd. I. as the Dean of the Faculty of Tarbiyah and Teacher Training of State Islamic Institute of Jember.

4. Dr. M. Hadi Purnomo, M.Pd. as the Chairman of the study program of Mathematics Education, Faculty of Tarbiyah and Teacher Training of State Islamic Institute of Jember.

5. Mr. Mohammad Mukhlis, S.Pd, M.Pd. as supervisor in this research.

6. Mrs. Afifah Nur Aini, M.Pd, Mr. Anas Ma'ruf Annizar, M.Pd, Mr. Dimas Danar Septiadi, M.Pd, Mr. Fikri Apriyono, S.Pd, M.Pd, Mrs. Masrurotullaily, M.Sc, Mr. Mohammad Kholil, M.Pd, Mr. Muh Harawan Dimas Jakaria, M.Pd, Dr. Hj. Umi Farihah, M.M, M.Pd, as mathematics lecturer of State Islamic Institute of Jember.

7. Best Friend Happy Firda Nuril Umami who has helped researchers in interpreting this research.

8. Students of Mathematics 1 (one) generation of 2018 who have been willing to be subjects in this research.

\section{REFERENCES}

Afifudin Dan Beni Ahmad. 2009. Metodologi Penelitian Kualitatif. Bandung: Pustaka Setia

Farihah, \& Nashihudin. 2014. The Analysis On Students' Errors in Solving Mathematical Word Problems of Cube and Block
Materials Based On the Stages of Newman's Error Analysis. Proceedings of International Seminar On Mathematics Education and Graph Theory. 449-457.

Goodlad, J. I. 1966. The Development of A Conceptual System For Dealing With Problems Of Curriculum And Instruction.

Karnasih, I. 2015. Analisis Kesalahan Newman Pada Soal Cerita Matematis (Newmans Error Analysis in Mathematical Word Problems). Jurnal Paradikma, 8(01), 37-51.

Mauji, S. M. 2019. Analisis Kesalahan Siswa Dalam Menyelesaikan Soal Trigonometri Berdasarkan Teori Newman (Doctoral Dissertation, Universitas Muhammadiyah Sukabumi).

Mukhlis, M., Dafik, D., \& Hobri, H. 2018. Student Critical Thinking in Solving Two Dimensional Armetics Problems Based On 21th Century Skills. International Journal of Advanced Engineering Research and Science, 5(4).

Mutakin, T. Z. 2015. Analisis Kesulitan Belajar Kalkulus 1 Mahasiswa Teknik Informatika. Formatif: Jurnal Ilmiah Pendidikan MIPA, 3(1).

Naim, Abu. 2010. Strategi Pembelajaran Islam Sekolah Islam Terpadu. Surakarta: Skripsi Fkip Ums

Nyaumwe, L. J. 2008. Zimbabwean High School Teachers 'Interpretations of Learners 'Alternative Conceptions On Selected Baseline Test Items On Calculus and Trigonometry Concepts. The Mathematics Educator, 11(2), 181-196.

Rahmawati, A. 2017. Analisis Kesalahan Mahasiswa Pendidikan Matematika Dalam Menyelesaikan Soal Pertidaksamaan Pada Mata Kuliah Kalkulus I. Al-Jabar: Jurnal Pendidikan Matematika, 8(1), 81-90.

Simmons, G. F. 2003. Precalculus Mathematics in A Nutshell: Geometry, Algebra, Trigonometry: Geometry, Algebra, Trigonometry. Wipf and Stock Publishers.

Sugiyono. 2010. Metode Penelitian Pendidikan Pendekatan Kuantitatif, Kualitatif Dan R\&D. Bandung: Alfabeta.

Satoto, S., Sutarto, H., \& Pujiastuti, E. 2012. Analisis Kesalahan Hasil Belajar Siswa dalam Menyelesaikan Soal dengan Prosedur Newman. Unnes Journal of Mathematics Education, $1(2)$

Tall, D., \& Vinner, S. 1981. Concept Image and Concept Definition in Mathematics with Particular Reference to Limits and Continuity. Educational Studies in Mathematics,

Wahyuni, A. 2017. Analisis Hambatan Belajar Mahasiswa Pada Mata Kuliah Kalkulus Dasar. JNPM (Jurnal Nasional Pendidikan Matematika), 1(1), 10-23 